\title{
Diet Quality and Risk Factors for Cardiovascular Diseases Among Adolescents from the Public Schools in a City in the Northeast Region of Brazil

Iara Samara de Lima Coutinho ${ }^{1}$, Adélia da Costa Pereira de Arruda1, Maria José de Carvalho Costa ${ }^{2}$, Flávia Emília Leite de Lima Ferreira ${ }^{2}$

\section{Abstract}

Background: Although clinical manifestations of cardiovascular disease (CVD) are observed, usually in the adult stage of life, there is strong evidence that these disorders can begin in adolescence. Few people who get a moderate to high risk for CVD at this stage can reverse this situation as an adult, which makes the monitoring of risk factors important element for detecting predisposition to the development of CVD in this population. Dietary modifications should form the basis for prevention of CVD, may reflect favorable changes in measurable risk factors. Dietary indices, such as the Healthy Eating Index (HEI) has been valid strategies for monitoring the power of a given population, and verification of cause and effect relationships in epidemiological studies

Methods: The present study aimed to analyze the association between quality of diet through the Brazilian Healthy Eating Index Revised(BHEI-R) and risk factors for cardiovascular diseases (CVD) in schoolchildren $(\mathrm{N}=1077)$ enrolled in the public school system, in the city of João Pessoa, Northeast Brazil. A cross-sectional study was performed and socio-demographic data and variables of risk factors for CVD were collected. Food intake was obtained from two $24 \mathrm{~h}$ food recalls. Ordinal logistic regression was used to identify the variables associated with the BHEI-R $(p<0.005)$.

Results: Lower time spent on sedentary behavior $(\mathrm{OR}=1.39 ; 95 \% \mathrm{Cl}=$ 1.03-1.87) and maternal level of education (OR=0.55; $95 \% \mathrm{Cl}=0.38$ $0.81)$ were associated with a higher BHEI-R score. There was an inadequate intake of "whole fruits" (1.2 points; SD=2.1), "whole cereals"
1 Programa de Pós-Graduação em Ciências da Nutrição, Universidade Federal da Paraíba-UFPB, João Pessoa, Paraíba, Brasil.

2 Programa de Pós-Graduação em Ciências da Nutrição-UFPB, Departamento de Nutrição, João Pessoa, Paraíba, Brasil.

\section{Contact information:}

Iara Samara de Lima Coutinho.

Address: Rua Morise de Miranda Gusmão, número 238, Cristo Redentor, João Pessoa, Paraíba. Brasil. CEP: 5807540.

Tel: +55(83)8609-8152.

”iarac@yahoo.com 
(1.3 points; SD=1.6), "milk and dairy products" (2.0 points; ST=3.0) and foods from the "solid fat and added sugar and alcohol" group (7.9 points; SD=6.3).

Conclusions: The importance of providing guidance on the reduction in sedentary behavior and performing actions that promote healthy eating should be emphasized among adolescents.

\section{Keywords}

Diet Quality Index; Cardiovascular Risk Factors; Adolescents; Food Intake.

\section{Background}

Although clinical manifestations of cardiovascular diseases (CVD) can be usually observed in adulthood, there is strong evidence that their risk factors can begin during adolescence [1]. As these factors tend to persist until one becomes an adult, very few people who have a moderate to high risk of CVD while they are young succeed in returning to a low level status simply by controlling the usual risk factors when they are adults [2], thus causing this to become an increasing public health problem worldwide [3].

The prevalence of risk factors for CVD in adolescents has been high, indicating that an increasing number of young people are exposed to two or more factors $[4,5]$. Additionally, other studies point out that the presence of risk factors during adolescence aggravates the development of CVD in this stage of life [1], being affected by atherogenesis, among other aspects.

In Brazil, the growing interest in analyzing dietetic exposure during adolescence and the occurrence of future diseases is one of the main factors that has contributed to the increase and improvement in schoolchildren monitoring systems [6].

According to the Pesquisa Nacional de Saúde do Escolar (PeNSE - National Survey on Schoolchidren's Health - 2012) [7], the consumption of snack foods (candies, drops, chocolate, chewing gum, bonbons or lollipops) on five or more days a week was reported by $41.3 \%$ of adolescents.
Dietary changes must be one of the key aspects in CVD prevention, both as a combination between healthy eating and an active lifestyle, which can translate into positive changes in measurable risk factors such as hypertension and overweight, and as a way to reduce the risk of a series of other chronic diseases [2].

Dietary indices such as the Diet Quality Index (DQI) have been valid strategies in the monitoring of eating habits of populations. Moreover, information about foods and nutrients incorporated into the DQI is used to observe the relationship with public health problems such as obesity and cancer [8]. In Brazil, this index was adapted and the Brazilian Diet Quality Index Revised (BHEI-R) was created [9].

The present study aimed to observe the association between diet quality and risk factors for CVD among adolescents enrolled in public schools of the city of João Pessoa, PB, Northeastern Brazil, with the purpose of providing support to the implementation of nutrition and food education actions focused on this population.

\section{Methods}

Cross-sectional study, the basis for the project entitled "Longitudinal Study on Sedentary Behavior, Physical Activity, Food and Health of Adolescents" (Estudo Longitudinal sobre Comportamento Sedentário, Atividade Física, Alimentação e Saúde dos Adolescentes - LONCAAFS) was, conducted with a representative sample of adolescents aged 10-15 
years, of both genders, enrolled in the sixth grade of the public primary school system in the city of João Pessoa, PB, Brazil. Data were collected from March to October 2014.

The sample was calculated from conglomerates and information obtained in the year before the beginning of this study was used. The city of João Pessoa had approximately 65,000 students enrolled in 184 public primary schools (93 state schools and 91 municipal schools). Among those students, approximately 9,500 were enrolled in the sixth grade in 128 schools (59 state schools and 69 municipal schools), distributed in four geographic regions of the city (north, south, east and west).

A total of 28 schools were systematically selected and distributed proportionally by type (14 municipal schools and 14 state schools), size (number of students enrolled in the sixth grade) and geographic region of the city. The following parameters were considered to determine the sample size: prevalence of low intake of fruits and vegetables; prevalence of overweight of 22\%; $4 \%$ error; $95 \%$ confidence interval; design effect (deff) equal to 2.0; and an additional 30\% for potential losses and refusals. Based on these parameters, the estimated sample size was 1026 students. The final study sample included 1077 adolescents. The exclusion criteria were pregnant women and individuals with disabilities that could prevent or limit the nutritional assessment or the understanding of the study and/or questionnaires.

A questionnaire evaluated the risk factors for CVD. The pre-test and calibration were performed in the year before data collection with a population similar to the current population. The questionnaire was administered through in-person interviews and it assessed the following aspects: sociodemographic profile, physical activity level, sedentary behavior, anthropometric measurements, blood pressure and dietary intake.

The physical activity level was assessed with a questionnaire [10] in which adolescents had the option of adding other physical activities as well as possible practical lessons at school. They were encouraged to list the physical activities performed in the previous week (days/week), describing their frequency and duration (hours, min/day). Adolescents who reported performing physical activity $\geq$ 300 min/week were considered "physically active" while the others were considered "physically inactive" [11].

Sedentary behaviors were assessed with questions about the time spent on activities such as watching television, videos and DVDs, playing video games, sitting or lying down while using a cell phone and/or tablet, and using a computer for homework, leisure and fun. They were assessed separately for weekdays (Monday to Friday) and weekends (Saturday and Sunday) [12].

For the final classification, the time spent on all the sedentary behaviors was added to obtain the mean number of hours per day, which was dichotomized into screen time $>2 \mathrm{~h} /$ day and screen time $\leq 2$ h/day [12].

\section{Anthropometry and blood pressure measurement}

Weight, height, waist circumference and blood pressure were measured in triplicate by the same person. The mean of the values obtained was used to minimize possible measurement errors. Subjects were weighed and measured without shoes and with minimal clothing, according to standard procedures [13].

Weight was measured using a Techline digital scale with a variation of $100 \mathrm{~g}$. Height was measured using a portable stadiometer. Next, the body mass index (weight $(\mathrm{kg}) /$ height $(\mathrm{m}) 2$ ) was calculated and expressed in Z-scores for each age. The nutritional status of adolescents was assessed based on the World Health Organization (WHO) criteria [14], with a BMI above $+1 \mathrm{Z}$ being classified as overweight and a BMI below $+1 \mathrm{Z}$ being classified as non-overweight. Waist circumference was measu- 
red using an inelastic tape measure at the midpoint between the lowest rib and the top of the iliac crest [15]. Values above or equal to the 80th percentile were considered as a metabolic and cardiovascular risk [16].

Blood pressure was measured in the right arm with the adolescent in a sitting position after five minutes of rest, with an automatic blood pressure monitor (Omron HEM - 7200) with cuff sizes appropriate for adolescents, calibrated periodically. Blood pressure was classified as high if the systolic blood pressure (SBP) had a Z-score above 1.25 [17].

\section{Diet quality}

Information about the food intake of adolescents was obtained from the 24-hour dietary recall (24HR), using the Automated Multiple-Pass Method (AMPM) [18]. The information about food and drink consumption, including the preparation and information about weight and serving size in grams, milliliters or household measures, were obtained using the Photographic Record for Diet Surveys (Registro Fotográfico para Inquéritos Dietéticos) [19], which provides pictures of food, kitchen utensils and standard measures that represent items or food servings that quantify the serving sizes more efficiently, minimizing potential memory deficits among research subjects.

Usual intake was estimated by adjusting for the within person variance of the nutrient intake using Multiple Source Method (MSM) [20]. This method can be used when

two or more $24 \mathrm{HDR}$ are available for at least a subsample of the individuals.

Two 24HRs were applied, the second was replied in a subsample of $25 \% 15$ to 90 days after the first application [21]. The food intake data were processed using Virtual Nutri Plus software.

Foods were grouped according to the Dietary Guidelines for the Brazilian Population (2006) and then evaluated according to the Brazilian Healthy Eating Index (BHEI) scores. BHEI is an index that evaluates the overall quality of diet of an individual or population through the distribution of scores among components, with a maximum value of 100 points indicating a better quality of diet. The distribution of the score is defined from the number of recommended daily servings of food groups per 1,000 kcal or mg/1,000 kcal for sodium, and a proportion of total energy consumption provided by nutrients, named SoFAAS( Solid fats, Alcohol and Added sugar) maintaining the agreement with the 2006 Dietary Guidelines recommendations [9].

For a more accurate classification of the BHEI-R components, according to the 2006 Dietary Guidelines, some preparations such as hot dogs, porridge, baião-de-dois (a typical Brazilian dish prepared with rice and beans) and fried banana were separated into their ingredients; the proportions of the ingredients were subsequently calculated when these preparations were grouped using a cookbook [22]. Information about added sugar and trans fat was obtained from the Table of Nutritional Composition of Foods Consumed in Brazil - Household Budget Survey (Pesquisa de Orçamentos Familiares - POF2008-2009) [23].

The maximum score ( 5 or 10 points) was attributed to a food intake greater than or equal to the recommended servings from the food groups per $1,000 \mathrm{kcal}$, and a score of 0 was given for the absence of intake; intermediate values were calculated in proportion to the amount consumed [24].

This project was approved by the Human Research Ethics Committee of the Federal University of Paraíba, and the Free and Informed Consent form was signed by parents/guardians.

\section{Data analysis}

Descriptive analysis of the variables was initially performed by calculating central tendency (mean and median), dispersion (standard deviation) and precision (95\% confidence interval). Frequency distribution was used for the variables measured on a nominal or ordinal scale, and mean and standard 
deviation were used for the variables measured on a numeric scale.

Multiple linear regression was used to correlate quality of diet with independent variables. Pearson correlation analysis was performed to determine which variables to include in the model; those with a correlation $p$-value of less than 0.20 were included in the model. The model used the BHEl score as the dependent variable.

Backward elimination was used to exclude variables from the regression model until only significant variables remained. Analyses were performed using SPSS 20.0. A significance level of $5 \%(p<0.05)$ was adopted for all analyses.

\section{Results}

Socio-demographic and anthropometric characteristics and risk factors for the population investigated are shown in Table 1. There were no statistical differences between the variables analyzed regarding sex, so that general population data are shown.

Mean age of the population was 12 years $(\mathrm{SD}=$ 1.05 ) and $54.1 \%$ were females. A total of $30.7 \%$ of mothers and $30.2 \%$ of fathers had completed secondary school or higher education and $74.6 \%$ of adolescents reported that they were non-white.

With regard to the variables associated with risk factors for cardiovascular diseases (CVD), the prevalence of overweight (BMI) was 33\%; $68.4 \%$ of adolescents spent $>2 \mathrm{~h} /$ day on sedentary behavior; $33 \%$ were categorized as physically inactive, i.e. they reported performing physical activity <300 min/week; $24.3 \%$ had a high waist circumference and $7 \%$ had high blood pressure (Table 1).

With regard to diet quality, there were no statistically significant differences when the means of the 12 components of the BHEI-R were compared between boys and girls.

Table 2 shows the low scores for the "oils", "whole fruits", "whole cereals" and "milk and dairy products" groups; high scores for the "saturated
Table 1. Distribution of the number and percentage of adolescents according to their socio-demographic characteristics and risk factors for cardiovascular disease. João Pessoa, PB, Brazil, 2014.

\begin{tabular}{|c|c|c|}
\hline Variable & $\mathbf{N}$ & $\%$ \\
\hline \multicolumn{3}{|l|}{ Gender } \\
\hline Male & 494 & 45.9 \\
\hline Female & 583 & 54.1 \\
\hline \multicolumn{3}{|c|}{ Paternal level of education (years of schooling) 1} \\
\hline$\leq 8$ years & 287 & 40.3 \\
\hline$>8$ year & 425 & 59.7 \\
\hline \multicolumn{3}{|c|}{ Maternal level of education (years of schooling) ${ }^{2}$} \\
\hline$\leq 8$ years & 400 & 44.8 \\
\hline$>8$ years & 493 & 55.2 \\
\hline \multicolumn{3}{|l|}{ Ethnicity $^{3}$} \\
\hline Whites & 273 & 25.4 \\
\hline Non-whites & 802 & 74.6 \\
\hline \multicolumn{3}{|l|}{ Overweight (BMI) 4} \\
\hline No & 715 & 67.0 \\
\hline Yes & 352 & 33.0 \\
\hline \multicolumn{3}{|c|}{ Waist circumference (CC) ${ }^{5}$} \\
\hline Normal & 813 & 75.7 \\
\hline Increased risk & 261 & 24.3 \\
\hline \multicolumn{3}{|l|}{ Blood pressure (systolic) 6} \\
\hline Normal & 1000 & 92.9 \\
\hline Increased & 76 & 7.1 \\
\hline
\end{tabular}

Sedentary behavior (TV/computer screen time)

\begin{tabular}{l|l|l|}
$\leq 2$ h/day & 340 & 31.6 \\
\hline$>2$ h/day & 737 & 68.4 \\
\hline Physical Activity Level & & \\
\hline$<300 \mathrm{~min} /$ week & 355 & 33.0 \\
\hline $300 \mathrm{~min} /$ week & 722 & 67.0 \\
\hline
\end{tabular}

1. 365 adolescents were unable to answer; ${ }^{2}: 84$ adolescents were unable to answer; ${ }^{3}$ : two adolescents were unable to answer;

4. 10 adolescents without data; ${ }^{5}$ : three adolescents without data; 6 : one adolescent without data. 
Table 2. Descriptive statistics of the scores of the Brazilian Healthy Eating Index Revised(BHEl- components among adolescents from public schools in the city of João Pessoa, PB, Brazil, 2014.

\begin{tabular}{|c|c|c|c|c|c|}
\hline Components & Mean (SD) & Median & $\begin{array}{c}\% \\
\text { Minimum score }\end{array}$ & $\begin{array}{c}\% \\
\text { Maximum score }\end{array}$ & $\begin{array}{c}\text { Score } \\
\text { variation }\end{array}$ \\
\hline Total fruit & $2.6(3.1)$ & 3.08 & 36.5 & 37.8 & $0-5$ \\
\hline Whole fruits & $1.2(2.1)$ & 0 & 73.2 & 21.6 & $0-5$ \\
\hline Total vegetables & $3.4(2.1)$ & 5 & 21.2 & 59.8 & $0-5$ \\
\hline Dark green and orange vegetables & $3.3(2.3)$ & 5 & 27.9 & 62.3 & $0-5$ \\
\hline Total Grain & $4.4(0.9)$ & 5 & 0.1 & 54.1 & $0-5$ \\
\hline Whole grain & $1.3(1.6)$ & 0 & 51.2 & 6.4 & $0-5$ \\
\hline Dairy products & $2.0(3.0)$ & 0 & 54.6 & 5.0 & $0-10$ \\
\hline Meat, eggs and legumes & $8.8(2.4)$ & 10 & 2.4 & 69.6 & $0-10$ \\
\hline Oils & $3.2(4.2)$ & 0 & 57.7 & 20.0 & $0-10$ \\
\hline Saturated Fat & $8.2(2.7)$ & 9.6 & 3.9 & 43.8 & $0-10$ \\
\hline Sodium & $6.8(3.1)$ & 7.6 & 5.6 & 20.9 & $0-10$ \\
\hline SoFAAS & $7.9(6.3)$ & 7.2 & 17.8 & 4.5 & $0-20$ \\
\hline BHEI-R final score & $52.3(13.3)$ & 52.3 & & & \\
\hline
\end{tabular}

fat", "total vegetables", "dark green and orange vegetables and legumes", "total cereals" and "meats, eggs and legumes"; and the mean BHEI-R, which was 52.17 ( $S D=13.31)$ with a variation from 10 to 89 points. In terms of the SoFAAS group, there was a low mean score (7.97 points) considering the fact that the maximum score for this group was 20.

Table 3 shows the final model of the ordinal logistic regression analysis $(p<0.05)$. After adjusting the model, there was a chance of adolescents having

Table 3. Ordinal logistic regression associating socio-demographic variables and risk factors for cardiovascular diseases and the Brazilian Diet Quality Index Revised (BHEl-R) of adolescent students from public schools in the city of João Pessoa, PB, Brazil, 2014. $\left(\mathrm{N}=885^{\star}\right)$.

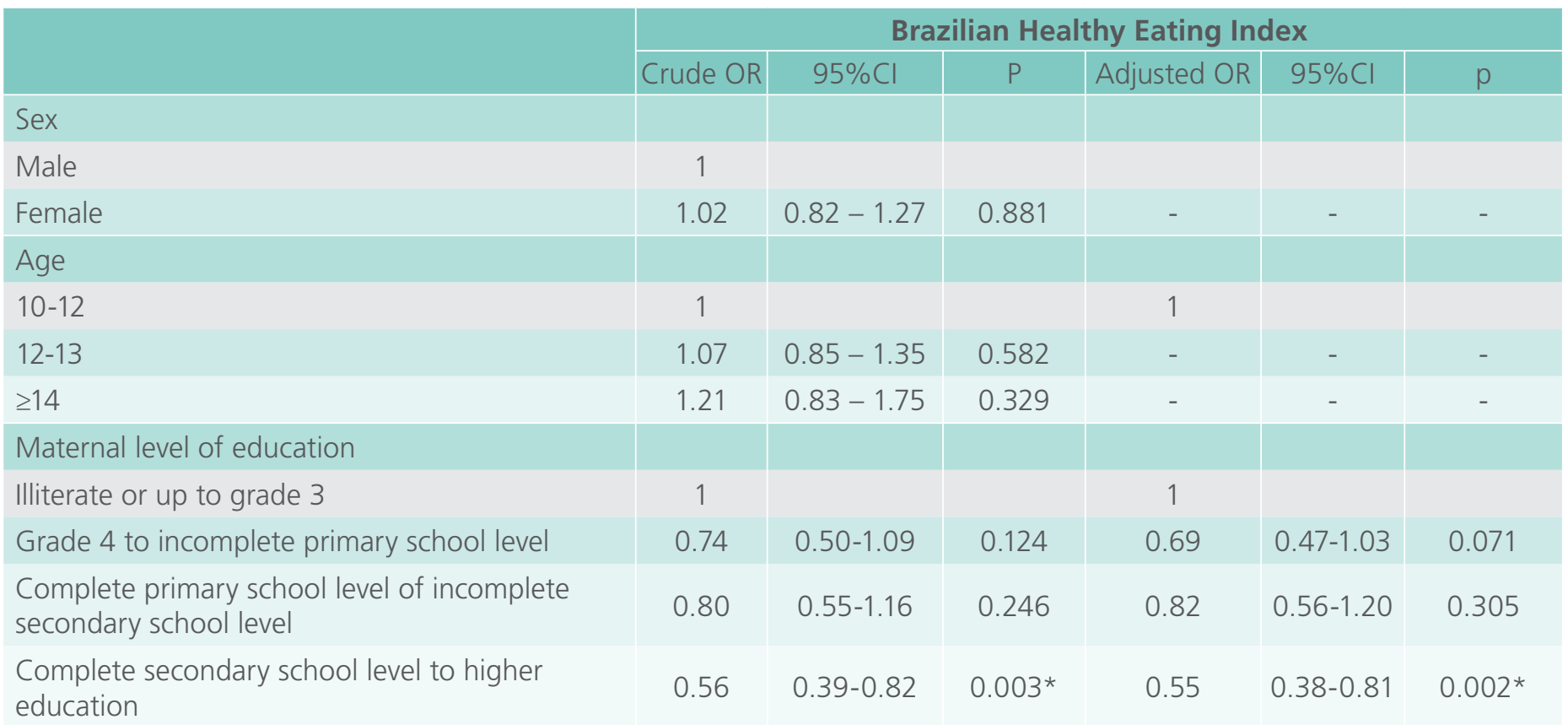




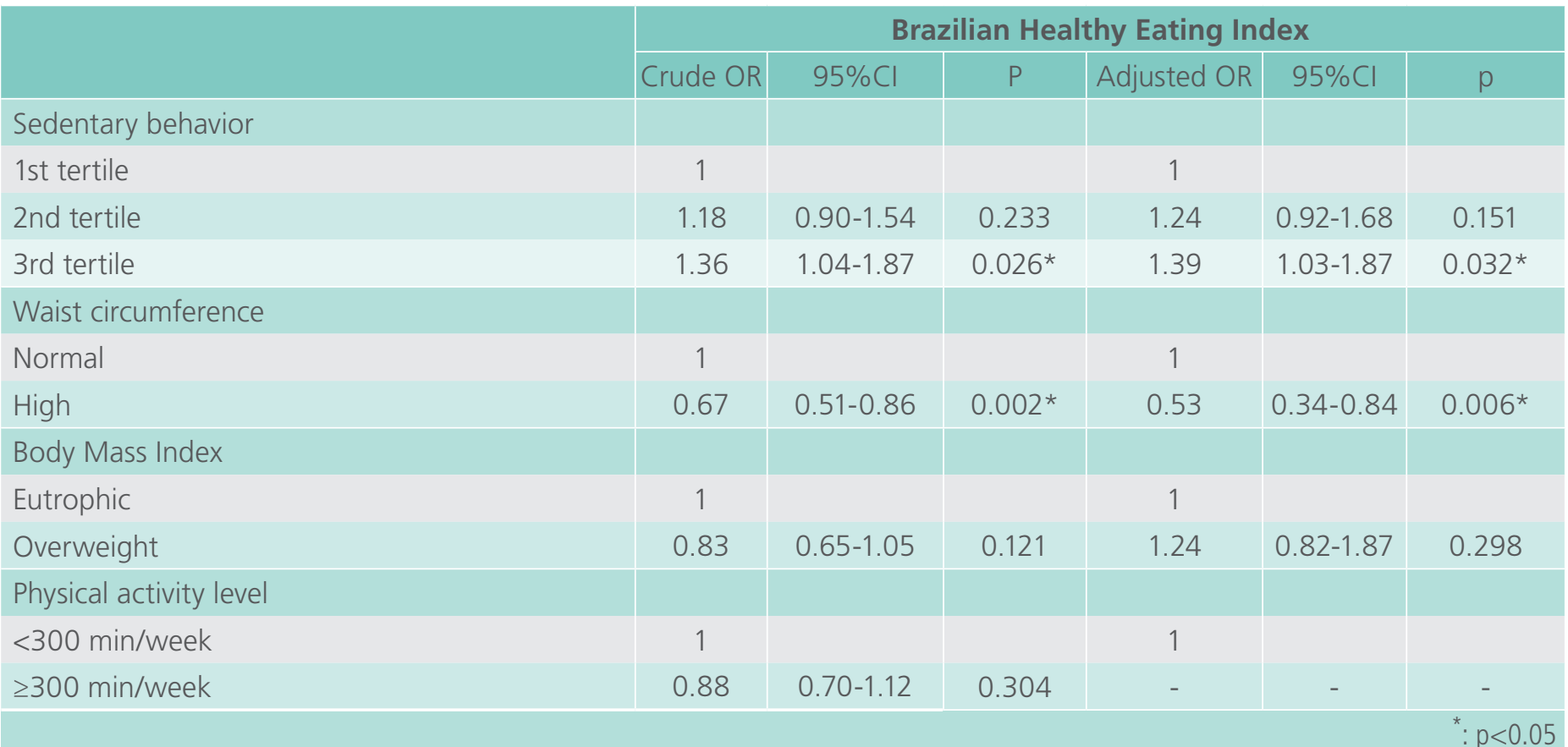

low quality of diet with the increase in time spent on sedentary behavior $(\mathrm{OR}=1.39 ; 95 \% \mathrm{Cl}=1.03$ 1.87). Respondents whose maternal level of education was higher had a lower chance of having an inadequate diet $(\mathrm{OR}=0.5595 \% \mathrm{Cl}=0.38-0.81)$. Paternal level of education was not included in the model due to the high non-response rate for this variable among adolescents.

Additionally, this model suggests that adolescents with a high waist circumference having better quality of diet $(\mathrm{OR}=0.53 ; 95 \% \mathrm{Cl}=0.34-0.84)$. Despite the Body Mass Index (BMI) not showing a significant association, this variable remained to adjust the model exclusively.

\section{Discussion}

The mean BHEI-R score of 52.3 observed in this study did not indicate a statistical difference between sexes. This score was similar to those found in the literature with Brazilian adolescents and in international studies $[25,26]$.

It is known that adolescents' eating habits are heavily influenced by the socioeconomic level of families and cultural aspects associated with food choices [27]. However, despite the frequent characterization of higher maternal level of education as a protective factor against poor quality of diet among adolescents, it is important to observe that factors associated with cardiovascular diseases (CVD) have also been connected to higher maternal levels of education [28].

Recently, some authors have argued that parents' eating habits and lifestyle are not associated with their children's quality of diet [29]. Thus, many studies need to incorporate the following into their methodology: the interrelations that family members have with one another, the family structure, and the influence of such relationships on eating the habits and lifestyle of adolescent students.

An unexpected positive relationship was found in this study between the increase in waist circumference and good quality of diet among adolescents. This relationship can indicate that, even if adolescents have good BHEI-R scores, a long time spent on sedentary activities can contribute to higher waist circumference levels as there was a high prevalence of sedentary adolescents in this population. 
In young individuals, the contribution of sedentary behavior to the relationship between diet and waist circumference needs to be further studied, given the fact that the literature still does not point to an association between quality of diet and waist circumference with regard to time spent on sedentary habits among adolescents. These factors are alarming, in view of the trend towards maintaining such habits during adulthood and the contribution of this behavior to the onset of and mortality from cardiovascular diseases [3].

In addition, this relationship can be explained by the possibility of reverse causality bias in the association between diet and waist circumference. Overweight adolescents tend to change the report of their diet as a result of their nutritional status [30].

Moreover, the adolescents' tendency towards reporting food intakes similar to those expected for the general population or eutrophic individuals [31, 32], should be taken into consideration. Selective underreporting can be the result of a higher level of knowledge about eating habits [33], as the dissemination of information about healthy eating has been increasing in schools, where adolescents can most frequently be found.

Furthermore, in terms of sedentary behavior, this study showed that adolescents who spent more time on sedentary activities were more likely to have a poorer quality of diet.

The practice of sedentary activities among adolescents is closely associated with the overuse of new technologies such as cell phones, video games and tablets, to the detriment of physical activities. This technological advance has increasingly contributed to physical inactivity not only in Brazil but worldwide. Thus, populations should be informed about the benefits of regular physical activities [34].

Important aspects such as passing fads imposed by the media and the influence when choosing manufactured or minimally processed products can be associated with the number of hours adoles- cents spend in front of a television and/or computer screen [35].

Despite eating habits differing among countries, these aspects are usually connected to the global trend towards consuming foods with a high energy content instead of those rich in fibers, leading to inadequate eating habits and physical inactivity itself [36].

The influence of the media and technology, apart from the convenience when eating (fast food), cause adolescents to choose artificial and/or highly processed foods over natural ones, as clearly observed in this population. This behavior was reflected in the high percentage of minimum score in the "total fruits", "whole fruits" and "whole cereals" groups of the BHEI-R, a fact that contributes to one's vulnerability to chronic non-communicable diseases (NCDs) such as cardiovascular diseases [2].

Additionally, low consumption of milk and dairy products has also been frequent in studies with adolescents in Brazil [37]. In this population, more than half of youngsters do not even consume half of the daily 1.5 servings/1,000 Kcal recommended by the Brazilian Population Food Guidelines, as observed in an European study with performed with adolescents [38]

According to authors, in order to understand this remarkable characteristic among adolescents, the growing habit of skipping meals, especially breakfast [47], and the replacement of milk and other milkbased drinks for sugary drinks such as artificial juices and sodas [39] must be taken into consideration. It should be emphasized that there was a high prevalence of consumption of these products in this population.

This characteristic can also be observed in the high intake of SoFAAS a group comprised by foods rich in solid fat, added sugar and alcohol. Although alcohol is part of this group, no adolescents reported having consumed alcoholic beverages.

Considering the fact that the increase in sugar and solid fat intake can be associated with risk fac- 
tors for the development of CVD in adolescents and subsequent adulthood [40], the identification of dietary factors can help to serve as a tool to reduce the risk of such diseases.

In conclusion, by analyzing the association between quality of diet and risk factors for CVD, the results of the present study confirm the trend towards a poorer quality of diet as adolescents have more sedentary time, corroborating the findings from international studies [38].

Although the study design enabled the associations among variables to be analyzed, its main limitation was the way the outcome was measured and the simultaneous exposure, which prevented temporality from being proved.

Our findings recommend the inclusion of actions aimed at promoting adherence to healthy eating habits associated with increased awareness of the importance of reducing sedentary behavior, thus helping to improve adolescents' quality of life and protection against CVD. Longitudinal studies are required to confirm the association between sedentary behavior and quality of diet and risk factors for cardiovascular diseases.

\section{Conclusion}

Few studies have assessed one's diet using the Brazilian Healthy Eating Index Revised (BHEl-R) associated with risk factors for CVD in adolescents in Brazil. Our results show the close relationship between poor eating habits and sedentary behavior, which facilitates the planning of public policies and the development of specific actions aimed at the promotion of physical activities and food and nutrition education.

\section{Acknowledgements}

We would like to thank FAPESq and CNPq for their financial support.

\section{References}

1. Beck CC, Lopes, AS, Giuliano, ICB, Borgatto, AF. Fatores de risco cardiovascular em adolescentes de município do sul do Brasil: prevalência e associações com variáveis sociodemográficas. Rev Bras Epidemiol 2011;14:36-49.

2. Magnussen, CG, Koskinen J, Juonala M, Chen W, Sathanur R, Sabin MA, et al. A diagnosis of the metabolic syndrome in youth that resolves by adult life is associated with a normalization of high carotid intima-media thickness and type 2 diabetes mellitus risk: the Bogalusa Heart and Cardiovascular Risk in Young Finns studies. J Am Coll Cardiol 2012;60:1631-1639.

3. MendisS, PuskaP,Norrving B. Globalatlasoncardiovasculardisease prevention and control. Geneva: World Health Organization. http://whqlibdoc.who.int/publications/2011/9789241564373 eng.pdf. (acsess on 07/May/2014).

4. Romanzini M, Reichert FF, Lops $A$, Petroski EL, Farias Júnior JC. Prevalência de fatores de risco cardiovascular em adolescentes. Cad Saúde Pública 2008;24:2573-2581.

5. Farias Júnior JC, Mendes JKF, Barbosa DBM, Lopes AS. Fatores de risco cardiovascular em adolescentes: prevalência e associação com fatores sociodemográficos. Rev Bras Epidemiol 2011;14:5062.

6. Malta DC, Sardinha LMV, Mendes I, Barreto SM, Giatti L, Castro IRR, et al. Prevalência de fatores de risco e proteção de doenças crônicas não transmissíveis em adolescentes: resultados da Pesquisa Nacional de Saúde do Escolar (PeNSE), Brasil, 2009. Ciênc Saúde Coletiva 2010;15: 3009-3019.

7. Instituto Brasileiro de Geografia e Estatística. Pesquisa Nacional de Saúde do Escolar (PeNSE)-2012. Rio de Janeiro: Instituto Brasileiro de Geografia e Estatística; 2012.

8. Evans WW, Jacques PF, Dallal GE, et al. The role of eating frequency on total energy intake and diet quality in a lowincome, racially diverse sample of choolchildren. Public Health Nutr 2015;18:475-481.

9. Previdelle NA, Andrade SC, Pires MM, et al. Índice de qualidade da Dieta Revisado para população brasileira. Rev Saúde Pública 2011;45:794-798.

10. Farias-Júnior JC, Lopes AS, Mota J, et al. Validade e reprodutibilidade de um questionário para medida de atividade física em adolescentes: uma adaptação do Self Administered Physical Activity Checklist. Rev Bras Epidemiol 2012; 15:198-210.

11. Dobbins $M$, DeCorby $K$, Robeson $P$, et al. School-based physical activity programs for promoting physical activity and fi tness in children and adolescents aged 6-18. Cochrane Database Syst Rev. 2009;21:CD007651. doi: 10.1002/14651858.CD007651.

12. Hardy LL, Dobbins $T$, Booth $M L$, et al. The reliability of the adolescent sedentary activity questionnaire (ASAQ). Prev Med 2007:45:71-74

13. Alvarez BR, Pavan AL. Alturas e comprimentos. In: Petroski EL. Antropometria: técnicas e padronizações. $4^{\mathrm{a}}$ ed. Blumenau, SC: Nova Letra, 2007;31-44. 
14. World Health Organization. Who child growth standards: length/height-for-age,weight-for-age, weightfor-length, weight-for-height and body mass index-for-age. Methods and development (nonserial publication). http://agris.fao.org/agrissearch/search.do?recordID=XF2006410216 (access on 12/ jan/2014)

15. World Health Organization. Obesity: preventing and managing the global epidemic. https://books.google.com. br/books?hl=pt-BR\&lr=\&id=AvnqOsqv9doC\&oi=fnd\&pg=PA $1 \& d q=$ Obesity:+preventing +and+managing +the +global+ep idemic. \&ots $=6$ UF95mXX5K\&sig $=-$ udE7nB4VR455Gk17CNO-

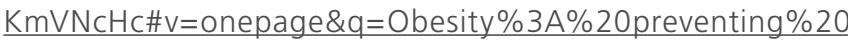
and $\% 20$ managing $\% 20$ the $\% 20$ global $\% 20$ epidemic. \&f=false (access on 15/mar/2014).

16. Taylor RW, Jones IE, Williams SM, Goulding A. Evaluation of waist circumference, waist-to-hip ratio, and the conicity index as screening tools for high trunk fat mass, as measured by dualenergy X-ray absorptiometry, in children aged 3-19 y. Am J Clin Nutr 2000;72:490-495.

17. National High Blood Pressure Education Program Working Group on High Blood Pressure in Children and Adolescents. The fourth report on the diagnosis, evaluation, and treatment of high blood pressure in children and adolescents. Pediatrics 2004; 114:555-76.

18. Moshfegh AJ, Rhodes DG, Baer DJ, Muravi T, Clemens JC, Rumpler WV, et al. The US Departamento $f$ Agriculture Automated Multiple-Pass Method reduces bias in the collection of energy intakes. Am J Clin Nutr 2008;88:324-332.

19. Zabotto CB, Vianna RPT, Gil MF. Registro fotográfico para inquéritos dietéticos: utensílios e porções. Goiânia: Editora Nepa-Unicamp, 1996.

20. Multiple Source Method (MSM) for estimating usual dietary intake from short-term measurement data. User Guide, 2011. 6th. Alemanha, DE: European Commission, Framework Programme, EFCOVAL work package 3A;2011.

21. Mohseni-takallo SM, Mirmiran P, Hosseini-esfahani F, Mehrabi Y, Azizi F. Metabolic Syndrome and its Association with Healthy Eating Index-2005 in Adolescents: tehran Lipid and Glusose study. J. Food Nutr Res 2014;2:155-161.

22. Fisberg RM, Villar BS. Manual de Receitas e Medidas Caseiras para Cálculo de Inquéritos Alimentares: manual elaborado para auxiliar o processamento de dados de inquéritos alimentares. São Paulo: Editora Signus, 2012.
23. Instituto Brasileiro de Geografia e Estatística. Tabelas de Composição Nutricional dos Alimentos Consumidos no Brasil. Pesquisa de Orçamentos familiares (POF) 2008-2009. Rio de Janeiro: Instituto Brasileiro de Geografia e Estatística; 2011

24. Wendpap LL, Ferreira MG, Rogério MR, Pereira RA, Loureiro AS, Gonçalves-Silva, RM. Índice de qualidade da dieta de adolescentes e fatores associados. Cad Saúde Pública 2014;30:97-106

25. Tanaka LF, Latorre MRDO, Silva AM, Konstantyner, ECM, Marques HHS. Poor diet quality among Brazilian adolescents with HIVIAIDS. J Pediatr 2015;91:152-159.

26. Assumpção D, Barros MBA, Fisberg RM, Carandina L, Goldbaum M, Cesar CL. Diet quality among adolescents: a populationbased study in Campinas, Brazil. Rev Bra Epidemiol 2011;15:605616.

27. Couto SF, Madruga SW, Neutzling MB, Silva MC. Frequência de adesão aos "10 Passos para uma Alimentação Saudável" em escolares adolescentes. Ciênc Saúde Colet 2014;19: 1589-1599.

28. Fernandes RA, Conterato I, Messias KP, Christofaro DGD, Oliveira AR, Júnior IF. Fatores de risco associados ao excesso de peso entre adolescentes da Região Oeste Paulista. Rev Esc Enferm 2009;43:768-773.

29. Vollmer RL, Adamsons K, Foster JS, Mobley AR. Association of fathers' feeding practices and feeding style on preschool age children's diet quality, eating behavior and body mass index. Appetite 2015:1;274-81.

30. Neutzling BC, Araújo LP, Vieira MFA, Hallal PCA, Menezes MB. Freqüência de consumo de dietas ricas em gordura e pobres em fibra entre adolescentes. Rev Saúde Pública 2007;41:2-7.

31. Cardoso LO, Alves LC, Castro IRR, leite IC, Machado CJ. Uso do método Grade of Membership na identificação de perfis de consumo e comportamento alimentar de adolescentes do Rio de Janeiro, Brasil. Cad. Saúde Pública 2011;27:335-346.

32. Souza AM, Pereira RA, Yokoo EM, Levy RB, Sichieri R. Alimentos mais consumidos no Brasil: Inquérito Nacional de Alimentação 2008-2009. Rev Saúde Pública 2013;47:191-199.

33. Dayrell C, Urasaki R, Goulart RMM, Ribeiro SML. Consumo alimentar e gasto energético em adolescentes obesos e eutróficos. Rev Paul Pediatr 2009;27:374-80.

34. Organização Mundial da Saúde: sedentarismo já é o quarto fator que mais mata no mundo. Zero Hora. http://zerohora. clicrbs.com.br/rs/noticia/2010/11/oms-sedentarismo-ja-e-oquarto-fator-que-maismata-no-mundo-3110558.html> (access on 12/mar/2014.).

35. Vasconcellos MB, Anjos LA, Vasconcellos TL. Estado Nutricional e tempo de tela de escolares da Rede pública de Ensino fundamental de Niterói, rio de Janeiro, Brasil. Cad Saúde Pública 2013;29:713-722 
36. Ghavamzadeh S, Khalkhali HR, Alizadeh M. TV Viewing, Independent of Physical Activity and Obesogenic Foods, Increases Overweight and Obesity in Adolescents. J Health Popul Nutr 2013;31:334-342.

37. Oliveira CF, Silveira CR, Beghetto $M$, Mello PD, Mello ED. Assessment of calcium intake by adolescentes. Rev Paul Pediatr 2014;32:216-220.

38. Moreno LA, Gottrand F, Huybrechts I, Ruiz JR, Gonzalèz-Gross $M$, DeHenauw S Nutrition and lifestyle in european adolescents: the HELENA (Healthy Lifestyle in Europe by Nutrition in Adolescence) study. Adv Nutr 2014;5:615-623.

39. Shafiee G, Kelishadi R, Qorbani M, Motlagh ME, Ardalan G, Taslimi M, et al. Association of breakfast intake with cardiometabolic risk factors. J Pediatr 2013;89:575-582.

40. Kell WP, Cardel MI, Bohan Brown MM, Fernàndez JR. Added sugars in the diet are positively associated with diastolic blood pressure and triglycerides in children. Am J Clin Nutr 2014;100:46-52.

Publish in International Archives of Medicine

International Archives of Medicine is an open access journal publishing articles encompassing all aspects of medical science and clinical practice. IAM is considered a megajournal with independent sections on all areas of medicine. IAM is a really international journal with authors and board members from all around the world. The journal is widely indexed and classified Q1 in category Medicine. 